\title{
Pyrazine as a building block for molecular architectures with PtII
}

Willermann, M ; Mulcahy, C ; Sigel, Roland K O ; Cerdà, M M ; Freisinger, Eva ; Sanz Miguel, P J ; Roitzsch, M ; Lippert, B

\begin{abstract}
A series of pyrazine (pz) complexes containing cis-(NH(3))(2) Pt(II), (tmeda) $\mathrm{Pt}(\mathrm{II})$ (tmeda $=\mathrm{N}, \mathrm{N}, \mathrm{N}^{\prime}, \mathrm{N}^{\prime}$-tetramethylethylenediamine), and trans-(NH(3))(2)Pt(II) entities have been prepared and characterized by X-ray crystallography and/or (1)H NMR spectroscopy. In these compounds, the pz ligands act as monodentate (1-3) or bidentate bridging ligands (4-7). Three variants of the latter case are described: a dinuclear complex $[\mathrm{Pt}(\mathrm{II})](2)(4 \mathrm{~b})$, a cyclic tetranuclear $[\mathrm{Pt}(\mathrm{II})](4)$ complex (5), and a trinuclear mixed-metal complex $[\mathrm{Pt}(2) \mathrm{Ag}](7)$. Mono- and bidentate binding modes are readily differentiated by (1)H NMR spectroscopy, and the assignment of pz protons in the case of monodentate coordination is aided by the observation of (195)Pt satellites. Formation of the open molecular box cis$[(\mathrm{NH}(3))(2) \mathrm{Pt}(\mathrm{pz})(4)](\mathrm{NO}(3))(8) \cdot 3.67 \mathrm{H}(2) \mathrm{O}(5)$ from cis-( $\mathrm{NH}(3))(2) \mathrm{Pt}(\mathrm{II})$ and pz follows expectations of the "molecular library approach" for the generation of a cyclic tetramer.
\end{abstract}

DOI: https://doi.org/10.1021/ic051966k

Posted at the Zurich Open Repository and Archive, University of Zurich

ZORA URL: https://doi.org/10.5167/uzh-1687

Journal Article

Accepted Version

Originally published at:

Willermann, M; Mulcahy, C; Sigel, Roland K O; Cerdà, M M; Freisinger, Eva; Sanz Miguel, P J; Roitzsch, M; Lippert, B (2006). Pyrazine as a building block for molecular architectures with PtII. Inorganic Chemistry, 45(5):2093-2099.

DOI: https://doi.org/10.1021/ic051966k 


\title{
Pyrazine as a Building Block for Molecular Architectures with Pt ${ }^{\mathrm{II}}$
}

\author{
Michael Willermann, Clodagh Mulcahy, ${ }^{+}$Roland K. O. Sigel, ${ }^{\#}$ Marta Morell Cerdà, Eva \\ Freisinger, ${ }^{\#}$ Pablo J. Sanz Miguel, Michael Roitzsch, and Bernhard Lippert ${ }^{*}$
}

Fachbereich Chemie, Universität Dortmund, 44221 Dortmund, Germany

Received

\begin{abstract}
A series of pyrazine (pz) complexes containing cis- $\left(\mathrm{NH}_{3}\right)_{2} \mathrm{Pt}^{\mathrm{II}}$, (tmeda) $\mathrm{Pt}^{\mathrm{II}}$, and trans$\left(\mathrm{NH}_{3}\right)_{2} \mathrm{Pt}^{\mathrm{II}}$ entities have been prepared and characterized by $\mathrm{X}$-ray crystallography and/or ${ }^{1} \mathrm{H}$ NMR spectroscopy. In these compounds, the pz ligands act as monodentate (1-3) or bidentate bridging ligands (4-7). Three variants of the latter case are described, a dinuclear complex $\left[\mathrm{Pt}^{\mathrm{II}}\right]_{2}(\mathbf{4 b})$, a cyclic tetranuclear $\left[\mathrm{Pt}^{\mathrm{II}}\right]_{4}$ complex $(\mathbf{5})$, and a trinuclear mixed-metal complex $\left[\mathrm{Pt}_{2} \mathrm{Ag}\right]$ (7). Mono- and bidentate binding modes are readily differentiated by ${ }^{1} \mathrm{H}$ NMR spectroscopy and the assignment of pz protons in the case of monodentate coordination is aided by the observation of ${ }^{195} \mathrm{Pt}$ satellites. Formation of the open molecular box cis$\left[\left\{\left(\mathrm{NH}_{3}\right)_{2} \mathrm{Pt}(\mathrm{pz})\right\}_{4}\right]\left(\mathrm{NO}_{3}\right)_{8} \cdot 3.67 \mathrm{H}_{2} \mathrm{O}(5)$ from cis- $\left(\mathrm{NH}_{3}\right)_{2} \mathrm{Pt}{ }^{\mathrm{II}}$ and $\mathrm{pz}$ follows expectations of the "molecular library approach" for the generation of a cyclic tetramer.
\end{abstract}

* $\quad$ Author to whom correspondence should be addressed:

E-mail: Bernhard.Lippert@uni-dortmund.de

$+\quad$ Present address: Royal College of Surgeons in Ireland, 123 St. Stephens Green, Dublin 2, Ireland.

\# Present address: Institute of Inorganic Chemistry, University of Zürich, 8057 Zürich, Switzerland. 


\section{Introduction}

By now, pyrazine (1,4-diazine, pz) can be considered a "classical" ligand in transition metal chemistry. To give a few examples: The so-called Creutz-Taube cation $\left[\left(\mathrm{NH}_{3}\right)_{5} \mathrm{Ru}^{\mathrm{II}}(\mathrm{pz}) \mathrm{Ru}^{\mathrm{III}}\left(\mathrm{NH}_{3}\right)_{5}\right]^{5+}$ with the bridging pyrazine ligand was instrumental in understanding intramolecular electron transfer (ET) in mixed valence state compounds. ${ }^{1}$ Later, pz-bridged metal complexes were applied in order to investigate possible magnetic exchange interactions between dinuclear metal entities. ${ }^{2}$ Even today ET between pyrazine-bridged $\mathrm{Ru}_{3}$ clusters is studied in combination with vibrational spectroscopy. ${ }^{3}$ Closely related to it, solvent dynamics properties are evaluated. ${ }^{4}$ Modifications of the basicity of the pyrazine ring as a consequence of coordination of transition metal fragments has been another area of topical research, ${ }^{5}$ as has been the fluxional behavior of this ligand. ${ }^{6}$ In recent years the use of pyrazine as a ditopic donor molecule has become common in the generation of coordination networks and metal-based supramolecular architectures. ${ }^{7,8}$ Finally, pyrazine-bridged dinuclear complexes of $\mathrm{Ru}$ and $\mathrm{Pt}$ have been prepared and studied with regard to their antitumor activity. $^{9}$

Our interest in the pyrazine ligand stems from its usefulness as a building block to generate distinct molecular architectures in combination with suitable transition metal ions. A few examples of such compounds exist, e.g. open Re boxes with luminescence properties, ${ }^{10} \mathrm{a}$ mixed-valence Creutz-Taube square, $\left[(\text { cyclen })_{4} \mathrm{Ru}_{4}(\mathrm{pz})_{4}\right]^{9+},{ }^{11}$ a titanocene box, ${ }^{7 \mathrm{i}}$ and molecular triangles obtained from cis- $\left(\mathrm{PMe}_{3}\right)_{2} \mathrm{Pt}^{\mathrm{II}}{ }^{12 \mathrm{a}}$ and $c i s-\left(\mathrm{PPh}_{3}\right)_{2} \mathrm{Rh}^{\mathrm{I}}{ }^{12 \mathrm{~b}}$

\section{Experimental Section}

Materials. Cis- $\left(\mathrm{NH}_{3}\right)_{2} \mathrm{PtCl}_{2},{ }^{13}$ (tmeda) $\mathrm{PtCl}_{2}{ }^{14}$ (tmeda $=N, N, N^{\prime}, N^{\prime}$-tetramethylethylenediamine) and trans-( $\left.\mathrm{NH}_{3}\right)_{2} \mathrm{PtCl}_{2}{ }^{14}$ were prepared as reported. Pyrazine (pz) was of a commercial source.

Synthesis of cis-[( $\left.\left.\mathbf{N H}_{3}\right)_{2} \mathbf{P t}(\mathbf{p z})_{2}\right]\left(\mathbf{N O}_{3}\right)_{\mathbf{2}}$ (1). Cis- $\left(\mathrm{NH}_{3}\right)_{2} \mathrm{PtCl}_{2}(203 \mathrm{mg}, 0.676 \mathrm{mmol})$ and $\mathrm{AgNO}_{3}(227.5 \mathrm{mg}, 1.339 \mathrm{mmol})$ were stirred in water $(25 \mathrm{~mL})$ in a stoppered flask with daylight excluded for $15 \mathrm{~h}$ at $40{ }^{\circ} \mathrm{C}$ and then filtered from $\mathrm{AgCl}$. Pyrazine (216.7 mg, 2.706 
mmol) was added to the clear filtrate and stirred for $3 \mathrm{~d}$ at room temperature. The solution was then evaporated to dryness. Under the conditions applied $\left(40{ }^{\circ} \mathrm{C}, 50 \mathrm{mbar}\right)$ excess $\mathrm{pz}$ is evaporated from the mixture. The residue was then washed with a small amount of water and EtOH to dissolve unreacted Pt starting material. Finally the sample was dried at $50{ }^{\circ} \mathrm{C}$. Yield $81 \%$. Elemental analysis calcd (\%) for $\mathrm{C}_{8} \mathrm{H}_{14} \mathrm{~N}_{8} \mathrm{O}_{6} \mathrm{Pt}$ (513.33): C, 18.7; H, 2.8; N, 21.8; found: C, 18.6; H, 2.6; N, 21.5. IR (KBr, v/cm $\left.{ }^{-1}\right) 3435 \mathrm{mb}, 3220 \mathrm{~s}, 3161 \mathrm{~s}, 1572 \mathrm{~m}, 1424 \mathrm{~s}$, 1362 vs, 1224 w, 1158 m, 1120 m, 1080 m, 881 w, 808 m, 661 w, 481 m. ${ }^{195}$ Pt NMR (D $\mathrm{D}_{2}$, $\delta / \mathrm{ppm})$-2540. Slow evaporation of a concentrated aqueous solution of 1 yielded colorless crystals suitable for X-ray analysis.

Synthesis of $\left[(\mathbf{t m e d a}) \operatorname{Pt}(\mathbf{p z})_{2}\right]\left(\mathrm{NO}_{3}\right)_{2} \cdot \mathrm{H}_{2} \mathrm{O}$ (2). The compound was prepared in analogy to 1. The yield was $58 \%$. Elemental analysis calcd (\%) for $\mathrm{C}_{14} \mathrm{H}_{26} \mathrm{~N}_{8} \mathrm{O}_{7} \mathrm{Pt}$ (613.57): C, 27.4; H, 4.3; N, 18.3; found: C, 27.1; H, 4.1; N, 18.5. IR (KBr, v/cm $\left.{ }^{-1}\right) 3447$ vs, 3095 m, 3004 m, 2922 m, 1637 m, 1384 vs, 1165 m, 1121 m, 1089 m, 824 m.

Synthesis of trans-[(NH$\left.)_{2} \mathbf{P t}(\mathbf{p z})_{2}\right]\left(\mathrm{NO}_{3}\right)_{2}$ (3). This compound was prepared in analogy to 1 and isolated in $85 \%$ yield. Elemental analysis calcd (\%) for $\mathrm{C}_{8} \mathrm{H}_{15} \mathrm{~N}_{8} \mathrm{O}_{6.5} \mathrm{Pt}$ (hemihydrate, 522.34): C, 18.4; H, 2.9; N, 21.5; found: C, 18.0; H, 2.7; N, 21.5. X-ray crystallography showed the compound to be anhydrous. IR (KBr, v/cm $\left.{ }^{-1}\right) 3180 \mathrm{~s}, 3128 \mathrm{~s}$, 3082 s, 3014 m, 1599 m, 1430 s, 1384 vs, 1328 vs, 1163 m, 1080 s, 824 m, 501 m. ${ }^{195} \mathrm{Pt}$ NMR $\left(\mathrm{D}_{2} \mathrm{O}, \delta / \mathrm{ppm}\right)-2534$.

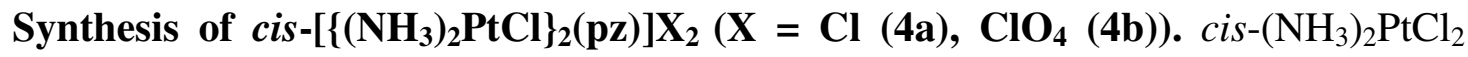
(500 mg, $1.67 \mathrm{mmol})$ and pz (63.4 mg, $0.79 \mathrm{mmol})$ were stirred in water $(20 \mathrm{~mL})$ at $40{ }^{\circ} \mathrm{C}$ for 3 days. After filtration of some elemental Pt, the solution was concentrated to a volume of 3 $\mathrm{mL}$ under a steady flux of $\mathrm{N}_{2}$. A bright yellow powder $(446 \mathrm{mg}$ ) was filtered off, washed with ethanol and ether and dried under vacuum to give $4 \mathbf{a}$. The yield was $79 \%$. Elemental analysis calcd (\%) for $\mathrm{C}_{4} \mathrm{H}_{16} \mathrm{~N}_{6} \mathrm{Cl}_{4} \mathrm{Pt}_{2}$ (680.18): C, 7.06; H, 2.37; N, 12.36; found: C, 6.8; H, 2.3; N, 12.2. IR (KBr, v/cm $\left.{ }^{-1}\right) 3301$ s, 3169 vs, 3099 vs, 3073 vs, 3017 m, 1560 m, 1438 s, 1361 s, $1320 \mathrm{~s}, 1174 \mathrm{~s}, 879 \mathrm{~m}, 835 \mathrm{~s}, 525 \mathrm{~s}, 341 \mathrm{~m}$.

Upon addition of a concentrated aqueous solution of $\mathrm{NaClO}_{4}(10 \mathrm{M} ; 45 \mu \mathrm{L})$ to the filtrate, a yellow microcrystalline material $\mathbf{4 b}$ precipitated, which was filtered off, washed 
with ethanol and ether and dried in air. 4b was isolated in $7.9 \%$ yield. Elemental analysis calcd (\%) for $\mathrm{C}_{4} \mathrm{H}_{16} \mathrm{~N}_{6} \mathrm{O}_{8} \mathrm{Cl}_{4} \mathrm{Pt}_{2}$ (808.18): $\mathrm{C}, 5.94 ; \mathrm{H}, 2.00 ; \mathrm{N}, 10.40$; found: $\mathrm{C}, 6.3 ; \mathrm{H}, 2.2 ; \mathrm{N}$, 10.5. IR (KBr, v/cm $\left.{ }^{-1}\right) 3302 \mathrm{~s}, 3218 \mathrm{~s}, 1636 \mathrm{~m}, 1559 \mathrm{~m}, 1433 \mathrm{~s}, 1339 \mathrm{~s}, 1312 \mathrm{~s}, 1084 \mathrm{vs}, 832 \mathrm{~s}$, 625 m, 338 m. ${ }^{195}$ Pt NMR (D $\left.20, \delta / p p m\right)-2319$.

Synthesis of cis- $\left[\left\{\left(\mathbf{N H}_{3}\right)_{2} \mathbf{P t}(\mathbf{p z})\right\}_{4}\right]\left(\mathbf{N O}_{3}\right)_{\mathbf{8}} \cdot \mathbf{3 . 6 7 \mathbf { H } _ { 2 }} \mathbf{O}$ (5). cis- $\left(\mathrm{NH}_{3}\right)_{2} \mathrm{PtCl}_{2} \quad(502 \mathrm{mg}$, $1.67 \mathrm{mmol})$ was suspended in water $(35 \mathrm{~mL})$ and $\mathrm{AgNO}_{3}(563 \mathrm{mg}, 3.31 \mathrm{mmol})$ was added. After $15 \mathrm{~h}$ at $40{ }^{\circ} \mathrm{C}$ in a stoppered flask and with daylight excluded, $\mathrm{AgCl}$ was filtered off and pz (134 mg, $1.67 \mathrm{mmol}$ ) was added. After $2 \mathrm{~d}$ at $40{ }^{\circ} \mathrm{C}$, the sample was brought to dryness by rotary evaporation $\left(40{ }^{\circ} \mathrm{C}, 50 \mathrm{mbar}\right)$, then washed with a small amount of water, and dried at $50{ }^{\circ} \mathrm{C}$. Yield $53 \%$. The pale greenish precipitate was then recrystallized from water to give crystals suitable for X-ray analysis. Elemental analysis calcd (\%) for $\mathrm{C}_{16} \mathrm{H}_{47.33} \mathrm{~N}_{24} \mathrm{O}_{27.67} \mathrm{Pt}_{4}$ (1799.1): C, 10.7; H, 2.7; N, 18.7; found: C, 10.8; H, 2.6; N, 18.8. IR (KBr, v/cm $\left.{ }^{-1}\right) 3420 \mathrm{mb}$, 3210 sb, 3106 s, 3070 s, 1588 m, 1455 s, 1352 vs, 1171 s, 1125 s, 976 w, 819 s, 522 m. ${ }^{195} \mathrm{Pt}$ $\operatorname{NMR}\left(\mathrm{D}_{2} \mathrm{O}, \delta / \mathrm{ppm}\right)-2535$.

Synthesis of $\left[\{(\text { tmeda }) \operatorname{Pt}(\mathbf{p z})\}\left(\mathrm{NO}_{3}\right)_{2} \cdot \mathbf{0 . 7 5 H}_{2} \mathrm{O}\right]_{\mathrm{n}}(\mathrm{n}=\mathbf{3}$ or 4) (6). An aqueous suspension (15 mL) of (tmeda) $\mathrm{PtCl}_{2}(500 \mathrm{mg}, 1.31 \mathrm{mmol})$ and $\mathrm{AgNO}_{3}(440 \mathrm{mg}, 2.59 \mathrm{mmol})$ was stirred for $24 \mathrm{~h}$ at $40^{\circ} \mathrm{C}$ with daylight excluded. The resultant $\mathrm{AgCl}$ precipitate was filtered off, pz (105 mg, $1.31 \mathrm{mmol})$ was added to the clear filtrate and this solution was stirred at room temperature for $24 \mathrm{~h}$. Volume reduction to $5 \mathrm{~mL}$ at $40^{\circ} \mathrm{C}$ on a rotary evaporator yielded a white precipitate which was filtered and washed with cold $\mathrm{H}_{2} \mathrm{O}(5 \mathrm{~mL})$ and dried at $40^{\circ} \mathrm{C}$. Yield $56 \%$. Elemental analysis calcd (\%) for $\mathrm{C}_{10} \mathrm{H}_{21.5} \mathrm{~N}_{6} \mathrm{O}_{6.75} \mathrm{Pt}: \mathrm{C}, 22.7 ; \mathrm{H}$, 4.1; N, 15.9; found: C, 22.3; H, 3.9; N, 15.9. IR $\left(\mathrm{KBr}, \mathrm{v} / \mathrm{cm}^{-1}\right): 3438 \mathrm{sb}, 3088 \mathrm{~m}, 3004 \mathrm{~m}$, 1637 m, 1426 m, 1386 vs, 1426 s , 1161 m, 1120 m, 1036 m, 994 m, 947 w, 812 m, 750 w, $524 \mathrm{~m}$.

Synthesis of $\left[\left\{(\text { tmeda }) \mathrm{Pt}(\mathrm{pz})_{2}\right\}_{2} \mathrm{Ag}\right]\left(\mathrm{ClO}_{4}\right)_{5} \cdot \mathbf{2} \mathrm{H}_{2} \mathrm{O}$ (7). Crystals of this compound were grown from an aqueous solution of $2(0.01 \mathrm{mmol}$ in $2 \mathrm{~mL})$ and $\mathrm{AgClO}_{4}(0.06 \mathrm{mmol})$ upon cooling $\left(3{ }^{\circ} \mathrm{C}\right)$ for several days. The compound was characterized by $\mathrm{X}$-ray crystallography. 
Spectroscopy and Other Measurements. ${ }^{1} \mathrm{H}$ NMR and ${ }^{195} \mathrm{Pt}$ NMR spectra were recorded on a Varian Mercury 200 FT NMR instrument with TSP (sodium 3-trimethylsilylpropanesulfonate) and $\mathrm{Na}_{2}\left[\mathrm{PtCl}_{6}\right]$ used as internal references $(\delta=0)$. The $\mathrm{pH}$ (uncorrected $\mathrm{pH}^{*}$ ) was adjusted by adding $\mathrm{NaOD}$ and $\mathrm{DNO}_{3}$, respectively, to $\mathrm{D}_{2} \mathrm{O}$ solutions of the samples and measured by means of a glass electrode. In order to determine the $\mathrm{p} K_{\mathrm{a}}$ of $\mathrm{pz}$ by $\mathrm{pH}$ dependent ${ }^{1} \mathrm{H}$ NMR spectroscopy, uncorrected $\mathrm{pH}^{*}$ values were converted into $\mathrm{pD}$ values by adding 0.4 to the $\mathrm{pH}$ meter reading. $\mathrm{p} K_{\mathrm{a}}$ values were evaluated with a Newton-Gauss ${ }^{16}$ nonlinear least-squares fit method. The obtained $\mathrm{p} K_{\mathrm{a}}$ value for $\mathrm{D}_{2} \mathrm{O}$ was then transformed to the value valid for $\mathrm{H}_{2} \mathrm{O}$ according to the literature. ${ }^{17} \mathrm{IR}$ spectra ( $\mathrm{KBr}$ pellets) were recorded on an IFS 28 FT spectrometer.

X-ray Crystallography. Crystal data for compounds 1, 3, 4b, 5, and $\mathbf{7}$ were collected on an Enraf-Nonius-KappaCCD diffractometer ${ }^{18}$ using graphite-monochromated MoK $\alpha$ radiation $(\lambda=0.7107 \AA)$. For data reduction and cell refinement, the programs DENZO and SCALEPACK (Nonius, 2000) ${ }^{19}$ were used. Absorption corrections based on the multiscan technique were applied for $\mathbf{4 b}$ and $\mathbf{5}$ using SADABS. ${ }^{20}$ The structures were solved by conventional Patterson methods and subsequent Fourier syntheses and refined by full-matrix least squares for $F^{2}$ using the SHELX program. ${ }^{21}$ The positions of all non-hydrogen atoms were deduced from difference Fourier maps and refined anisotropically. Hydrogen atoms were included in calculated positions and refined with isotropic displacement parameters. In 7 one of the perchlorate anions $(\mathrm{Cl}(3))$ is disordered over two positions, with one of the oxygen atoms lying on the twofold axis.

\section{Results and Discussion}

Pyrazine as a Monodentate Ligand. Three compounds, cis- $\left[\left(\mathrm{NH}_{3}\right)_{2} \mathrm{Pt}(\mathrm{pz})_{2}\right]$ $\left(\mathrm{NO}_{3}\right)_{2} \cdot \mathrm{H}_{2} \mathrm{O}(\mathbf{1})$, [(tmeda) Pt $\left.(\mathrm{pz})_{2}\right]\left(\mathrm{NO}_{3}\right)_{2} \cdot \mathrm{H}_{2} \mathrm{O}(\mathbf{2})$, and trans-[( $\left.\left.\mathrm{NH}_{3}\right)_{2} \mathrm{Pt}(\mathrm{pz})_{2}\right]\left(\mathrm{NO}_{3}\right)_{2}(\mathbf{3})$, which contain pyrazine as monodentate ligands, were prepared. X-ray crystal structure analyses were performed for $\mathbf{1}$ and 3. The cations of $\mathbf{1}$ and $\mathbf{3}$ are depicted in Figures 1 and 2, and salient structural features are listed in the legend. In $\mathbf{1}$ the Pt coordination geometry is close to ideal square-planar as far as angles are concerned. Pt-N distances are normal. The pz planes are 
tilted toward the $\mathrm{PtN}_{4}$ planes with angles of $50.5(2)^{\circ}$ (ring a) and $66.2(2)^{\circ}$ (ring b). The angle between the two pz rings is $73.6(2)^{\circ}$. There are no unusual features in the pz rings. Expectedly, the internal ring angles at $\mathrm{N} 1$ and $\mathrm{N} 4$ of the pz ligands are different and larger for the $\mathrm{N} 1$ sites carrying the heavy metal. Cations of $\mathbf{1}$ interact through weak centrosymmetric hydrogen bonds between the non-coordinating ring-nitrogen atom of pyrazine (N4) and the heteroaromatic protons in the $\alpha$-position (Figure 3). Between a-rings these distances are 3.283(9) $\AA$, whereas they are 3.264(8) $\AA$ between b-rings. Although these distances are relatively long and clearly longer than in hemiprotonated phenanthroline, ${ }^{22}$ they can still be considered hydrogen bonds. ${ }^{23,24}$ As a consequence of these interactions, cations of $\mathbf{1}$ form a zigzag chain along the z-axis and Pt centers are lined up along the x-axis (5.819(1) $\AA$ ). The nitrate anions are located between the zigzag chains and form multiple $\mathrm{H}$ bonds to $\mathrm{NH}_{3}$ groups and long contacts to Pt centers, e.g. 3.581(5) A between Pt and O2n (x+1, y, z). The presence of nitrate anions prevents any stacking between pz ligands.

There are no unusual features with the cation of trans $-\left[\left(\mathrm{NH}_{3}\right)_{2} \mathrm{Pt}(\mathrm{pz})_{2}\right]\left(\mathrm{NO}_{3}\right)_{2}(3)$. The pz ligands form angles of $70.9(1)^{\circ}$ with the $\mathrm{PtN}_{4}$ plane. Cations form columns extending along the z-axis, with distances of $7.7 \AA$ between pz rings. Pairs of nitrate anions are located between the cations and form bifurcated hydrogen bonds with $\mathrm{NH}_{3}$ ligands of two different cations. In addition, the remaining proton of each $\mathrm{NH}_{3}$ ligand forms a $\mathrm{H}$ bond with nitrate-O1 of an adjacent column. The lengths of the NH...O bonds vary between 2.953(4) and 3.018(5) $\AA$.

Pyrazine as a Bridging Ligand. The reaction of pyrazine with an excess of cis-

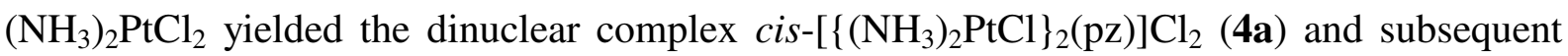
recrystallization in the presence of $\mathrm{NaClO}_{4}$ gave the corresponding perchlorate salt $(\mathbf{4 b})$, the structure of which was established by X-ray crystallography. A view of $\mathbf{4 b}$ is given in Figure 4 and selected interatomic distances and angles are listed in the legend. The coordination spheres of the two heavy metal atoms do not show any peculiarities. Pt-N (pz) distances are identical within standard deviations and on average 2.025(5) $\AA$. The same is true for $\mathrm{Pt}-\mathrm{NH}_{3}$ distances (av. 2.039(5) $\AA$ ). There is no structural trans-influence of the $\mathrm{Cl}$ ligands on $\mathrm{Pt}-\mathrm{NH}_{3}$ bond lengths vs. the pz ligand. As expected, twofold Pt binding leads to identical internal ring angles at $\mathrm{N} 1\left(117.4(5)^{\circ}\right)$ and $\mathrm{N} 4\left(117.7(5)^{\circ}\right)$ of the pz ring. The angles between the cis$\left(\mathrm{NH}_{3}\right)_{2} \mathrm{Pt}^{\mathrm{II}}$ units and the pz plane are different for Pt1 $\left(83.4(3)^{\circ}\right)$ and $\mathrm{Pt} 2\left(69.3(4)^{\circ}\right)$. As a result, the angle between the two $\mathrm{PtN}_{3} \mathrm{Cl}$ planes is $27.4(5)^{\circ}$. There is extensive intermolecular 
hydrogen bonding between pairs of cations involving $\mathrm{Cl}$ and $\mathrm{NH}_{3}$ ligands $(\mathrm{N}(22) \ldots \mathrm{Cl}(11)$, $3.530(8) \AA ; \mathrm{N}(22) . . \mathrm{Cl}(21), 3.403(6) \AA)$ as well as multiple hydrogen bonds between oxygen atoms of the $\mathrm{ClO}_{4}{ }^{-}$anions and $\mathrm{NH}_{3}$ groups (distances 2.84(2) - 3.39(2) $⿱$ ). Figure 5 provides two views of a pair of cations (with hydrogen bonded anions omitted for clarity) which reveal that the two pz rings are parallel, yet do not overlap. The closely related compound cis$\left[\left\{\left(\mathrm{NH}_{3}\right)_{2} \mathrm{PtCl}\right\}_{2}(\mathrm{pz})\right]\left(\mathrm{NO}_{3}\right)_{2}$ has been reported before, ${ }^{9 \mathrm{~b}}$ but its cation is centrosymmetric, hence the $\mathrm{Cl}$ ligands are pointing into opposite directions, unlike in $\mathbf{4 b}$. $\mathrm{Pt}-\mathrm{N}$ and $\mathrm{Pt}-\mathrm{Cl}$ bonds are very similar in the two compounds.

A Pyrazine Box. Consistent with expectations following the "molecular library approach", ${ }^{25}$ a tetranuclear pyrazine box cis- $\left[\left\{\left(\mathrm{NH}_{3}\right)_{2} \mathrm{Pt}(\mathrm{pz})\right\}_{4}\right]\left(\mathrm{NO}_{3}\right)_{8} \cdot 3.67 \mathrm{H}_{2} \mathrm{O}$ (5) was obtained and isolated upon reacting cis- $\left[\left(\mathrm{NH}_{3}\right)_{2} \mathrm{Pt}\left(\mathrm{H}_{2} \mathrm{O}\right)_{2}\right]^{2+}$ and $\mathrm{pz}$ in a 1:1 ratio. Formation of 5 was also observed by ${ }^{1} \mathrm{H}$ NMR spectroscopy in a number of other cases, for example upon mixing cis- $\left[\left(\mathrm{NH}_{3}\right)_{2} \mathrm{Pt}(\mathrm{pz})_{2}\right]^{2+}$ and cis- $\left[\left(\mathrm{NH}_{3}\right)_{2} \mathrm{Pt}\left(\mathrm{D}_{2} \mathrm{O}\right)_{2}\right]^{2+}$, and identified by its characteristic singlet resonance in the ${ }^{1} \mathrm{H}$ NMR spectrum (see below). It is interesting to note that Stang and Cao did not observe formation of a cyclic tetramer when employing (dppp) $\mathrm{Pt}^{\mathrm{II}}$ (dppp = 1,3bis(diphenylphosphino)propane $\left.{ }^{26}\right)$ instead of cis- $\left(\mathrm{NH}_{3}\right)_{2} \mathrm{Pt}^{\mathrm{II}}$, which the authors attributed to both electronic and steric factors. However, as mentioned in the introduction, with cis$\left(\mathrm{PMe}_{3}\right)_{2} \mathrm{Pt}^{\mathrm{II}}$ a triangular complex can be isolated. ${ }^{12 \mathrm{a}}$ Compound 5 crystallizes with two independent cations, (I) and (II). Figures 6 gives a view of one of it (I). In (I) the four metal ions Pt1-Pt4 are essentially coplanar. The pyrazine rings are inclined with respect to the $\mathrm{Pt}_{4}$ plane. Dihedral angles (av. for two adjacent Pt coordination planes each) are 68.4(3) ${ }^{\circ}$ for ring “a”, 78.9(3) ${ }^{\circ}$ for ring “b”, 61.2(3) ${ }^{\circ}$ for ring “c", and 69.7(3) $)^{\circ}$ for ring "d". Pt...Pt distances along the sides are between 6.79(1) and 6.81(1) $\AA$, and the separations across the diagonal are 9.59(1) (Pt1...Pt3) and 9.66(1) ^ (Pt2...Pt4). The second tetranuclear cation (II), which is located at a center of inversion, displays rather similar structural details, except for dihedral angles between $\mathrm{pz}$ rings and the $\mathrm{Pt}_{4}$ plane. These are $68.8(3)^{\circ}$ for rings " $\mathrm{f}$ " and $89.3(3)^{\circ}$ for rings "e". The size of the open pyrazine boxes of $\mathbf{5}$ thus is slightly smaller than that of the $\mathrm{Ru}_{3}^{\mathrm{II}} \mathrm{Ru}^{\mathrm{III}}(6.96 \AA)^{11}$ and $\mathrm{Ti}_{4}(7.20 \AA)^{7 \mathrm{i}}$ boxes, yet clearly larger than that of the related $\mathrm{Pt}_{4}$ uracil box, ${ }^{27}$ in which the Pt-Pt distances along the edges are shorter by almost $1 \AA$. $\mathrm{Pt}-\mathrm{NH}_{3}$ and Pt-N(pz) bond lengths in $\mathbf{5}$ are on average 2.04(2) and 2.02(2) $⿱$, respectively, and thus in the normal range. Angles about the Pt atoms deviate by up to $2.1(4)^{\circ}$ from $90^{\circ}$, which is likewise normal. 
Cations of 5, nitrate anions, and water molecules (5.5 molecules per 1.5 formula units) form a tight network of hydrogen bonds involving the $\mathrm{NH}_{3}$ ligands. There are also weak contacts between oxygen atoms of nitrate anions and aromatic pyrazine protons (3.0 -3.4 $\AA$ ). One of the nitrate anions (N30) is unique in that one of its oxygen atoms, O33, is partially inserted in the cavity provided by the four pz rings in cation (I) (Figure 7). It is thus a situation different from that seen in larger cavities of metal hosts. ${ }^{28}$ The nitrate oxygen atom which protrudes furthest from the box, O31, makes a weak axial contact with a $\mathrm{Pt}$ atom $(\mathrm{Pt} 2 \mathrm{a}$, 3.51(1) $\AA$ ) of an adjacent box. The angle formed between the nitrate anion and the Pt4 plane is $84.8(4)^{\circ}$. None of the other nitrates behaves analogously.

In analogy to 5, complex 6 was obtained from (tmeda) $\mathrm{Pt}^{\mathrm{II}}$ and pyrazine. It is presently unclear whether $\mathbf{6}$ is indeed a cyclic tetramer or a cyclic trimer only (see below).

A Mixed Pt,Ag Polymer. Cocrystallization of [(tmeda) $\left.\mathrm{Pt}(\mathrm{pz})_{2}\right]\left(\mathrm{NO}_{3}\right)_{2} \cdot \mathrm{H}_{2} \mathrm{O}(2)$ with $\mathrm{AgClO}_{4}$ gave $\left[\left\{(\text { tmeda }) \mathrm{Pt}(\mathrm{pz})_{2}\right\}_{2} \mathrm{Ag}\right]\left(\mathrm{ClO}_{4}\right)_{5} \cdot 2 \mathrm{H}_{2} \mathrm{O}(7)$. In the cation of $\mathbf{7}, \mathrm{a} \mathrm{Ag}^{+}$ion crosslinks the N4 sites of one pz ligand of cation 2 in a linear fashion, with $\mathrm{Ag}-\mathrm{N} 4$ distances of 2.320(4) $\AA$ (Figure 8). These distances are identical with those observed in a related heteronuclear complex of type Co-pz-Ag-pz-Co. ${ }^{29}$ The overall shape of the cation of $\mathbf{6}$ is thus that of a Z. The Pt-N1 (pz) distances are normal (av. 2.029(4) $\AA$ ), and the separations between the heavy metals amount to 7.118(1) $\AA$ for $\operatorname{Pt}(1) \ldots \operatorname{Ag}(1)$, and to $14.237(2) \AA$ for $\operatorname{Pt}(1) \ldots \operatorname{Pt}(1 \mathrm{a})$ due to the centrosymmetry. The most interesting feature of 7 is the way in which individual cations interact (Figure 9). Thus, the N(4c) sites of the pz ligands form long contacts of 2.586(4) $\AA$ with the Ag ions of adjacent cations, which results in the appearance of infinite open $\mathrm{Pt}_{2} \mathrm{Ag}_{2 / 2}$ boxes. The four metals are planar. Angles at the $\mathrm{Ag}$ centers are $79.7(1)^{\mathrm{o}}$ and $100.3(1)^{\circ}$ and at the $\mathrm{Pt}$ centers they vary between $85.1(2)^{\circ}(\mathrm{N}(1 \mathrm{e})-\mathrm{Pt}(1)-\mathrm{N}(2 \mathrm{e}))$ and $93.7(2)^{\circ}(\mathrm{N}(2 \mathrm{e})-\mathrm{Pt}(1)-\mathrm{N}(1 \mathrm{~b}))$. Within the heteronuclear box intermetallic distances are $9.780(2) \AA(\operatorname{Pt}(1 \mathrm{c}) \ldots \operatorname{Pt}(1 \mathrm{e})), 10.663(2) \AA(\operatorname{Ag}(1 \mathrm{a}) \ldots \mathrm{Ag}(1 \mathrm{~b})), 7.118(1) \AA(\operatorname{Pt}(1 \mathrm{a})-\operatorname{Ag}(1 \mathrm{a}))$, and 7.349(1) ̊ $(\operatorname{Ag}(1 \mathrm{a}) \ldots \operatorname{Pt}(1 \mathrm{~b}))$.

The polymeric arrangement of the open pz boxes leads to a tape structure with a highly hydrophobic surface generated by the $\mathrm{CH}$ groups of the pz ligands as well as the $\mathrm{CH}_{2}$ and $\mathrm{CH}_{3}$ groups of the tmeda ligands, which is interrupted by "holes" in the center of the boxes and between the Pt atoms lined up at the periphery of the tape (Figure 9). Piles of such tapes are at a distance of $6.7 \AA$ (between metal planes) and shifted in such a way that each $\mathrm{Ag}^{+}$of one tape is located above the center of the $\mathrm{Pt}_{2} \mathrm{Ag}_{2 / 2}$ box of the adjacent tape. Similarly, 
the Pt atoms at the periphery of the tape are on interstitial sites. The repulsion between the positively charged tapes is minimized by perchlorate anions. $\mathrm{O}(41)$ of $\mathrm{Cl}(1) \mathrm{O}_{4}{ }^{-}$is inserted into the "hole" within the $\mathrm{Pt}_{2} \mathrm{Ag}_{2 / 2}$ box, hence is involved in a host-guest interaction with the cationic box (Figure 10), while one of the other oxygen atoms, $\mathrm{O}(31)$, forms a weak contact of 2.920(4) $\AA$ to the $\mathrm{Ag}^{+}$ion above. Similarly, $\mathrm{O}(22)$ of $\mathrm{Cl}(2) \mathrm{O}_{4}{ }^{-}$has a long contact with $\mathrm{Pt}$ via an axial position (3.793(4) $\AA$ ).

The disordered $\mathrm{ClO}_{4}^{-}$anions (c.f. Experimental) are positioned between individual piles.

${ }^{1}$ H NMR Spectra. As expected, the ${ }^{1} \mathrm{H}$ NMR spectrum of free pz consists only of a singlet (8.64 ppm; $\mathrm{D}_{2} \mathrm{O} ; \mathrm{pD} 3-9$ ). Below $\mathrm{pD} \sim 3$ the resonance moves downfield due to protonation of the ring $\mathrm{N}$ atoms, with a shift of $\simeq 9.2 \mathrm{ppm}$ reached at $\mathrm{pD} \simeq 0.4$. The $\mathrm{p} K_{\mathrm{a} 1}$ value determined from $\mathrm{pD}$ dependent ${ }^{1} \mathrm{H}$ NMR spectra was $0.9 \pm 0.1\left(\mathrm{D}_{2} \mathrm{O}\right)$, which corresponds to $0.5 \pm 0.1$ for water. This value is in good agreement with literature data. ${ }^{30}$

The ${ }^{1} \mathrm{H}$ NMR spectra of complexes containing pz bound in a monodentate fashion to $\mathrm{Pt}^{\mathrm{II}}$ are complex due to ${ }^{1} \mathrm{H},{ }^{1} \mathrm{H}$ coupling in a $\mathrm{AA}^{\prime} \mathrm{BB}^{\prime}$ system. Consequently the four $\mathrm{pz}$ protons in 1, 2, and $\mathbf{3}$ are split into two multiplets due to vicinal and long range coupling (Figure 11).

Moreover, both sets of resonances display ${ }^{195} \mathrm{Pt}$ coupling of different magnitude, which permits an assignment of the protons. Thus, the set displaying the larger ${ }^{195} \mathrm{Pt}$ coupling constant $\left({ }^{3} \mathrm{~J}\right.$, ca. $\left.40 \mathrm{~Hz}\right)$ is assigned to $\mathrm{H} 2$ and $\mathrm{H} 2$ ' protons in ortho positions to $\mathrm{Pt}$, while the set showing smaller coupling $\left({ }^{4} \mathrm{~J}, \mathrm{ca} .11 \mathrm{~Hz}\right)$ is assigned to the protons in meta positions, $\mathrm{H} 3$ and $\mathrm{H} 3{ }^{\prime}$.

A comparison of chemical shifts (center of each mutiplet) of cis- and trans-isomers 1 and 3 reveals $\mathrm{H} 3$ and $\mathrm{H}^{3}$ ' resonances slightly upfield (ca. $0.1 \mathrm{ppm}$ ) in the case of the cis compound, which probably is a consequence of the ring current imposed by the other pz ligand (Table 2).

The ${ }^{1} \mathrm{H}$ NMR spectrum of $\mathbf{4 b}$ is again very simple, having a sharp singlet at $9.04 \mathrm{ppm}$ $\left(\mathrm{D}_{2} \mathrm{O}\right)$ and well resolved ${ }^{195} \mathrm{Pt}$ satellites of $36 \mathrm{~Hz}$. This coupling constant is at the upper end of neutral compounds of composition trans, trans- $\left[\left\{\mathrm{PtCl}_{2}\left(\mathrm{R}_{2} \mathrm{SO}\right)\right\}_{2}(\mathrm{pz})\right]$ which display ${ }^{3} J$ values of 28-35 Hz in $\mathrm{CDCl}_{3}{ }^{31}$ The open box 5 likewise displays a singlet, which occurs at $9.18 \mathrm{ppm}$ $\left(\mathrm{D}_{2} \mathrm{O}, \mathrm{pD} 4.3\right)$ and has two sets of ${ }^{195} \mathrm{Pt}$ satellites due to ${ }^{4} J$ coupling $(5 \mathrm{~Hz})$ and ${ }^{3} J$ coupling of $32 \mathrm{~Hz}$ (Figure 10). The singlet nature of the pz protons of $\mathbf{6}$ is consistent with a bridging mode, 
and relative intensities of tmeda and pz resonances unambiguously confirm a cyclic structure. We tentatively assign a tetranuclear structure to $\mathbf{6}$, although we note that the pz singlet is substantially shifted to lower field $(9.497 \mathrm{ppm})$ as compared to 5. If the $c i s-\mathrm{a}_{2} \mathrm{Pt}(\mathrm{pz})_{2}$ compounds $\mathbf{1}$ and $\mathbf{2}$ are taken as a reference (mean of H2,H2' and H3,H3'), the downfield shift in 5 is $0.16 \mathrm{ppm}$, yet $0.50 \mathrm{ppm}$ in the case of $\mathbf{6}$. This difference may point to a cyclic structure of $\mathbf{6}$ other than that of a tetramer, e.g. of a trimer. Unfortunately, our attempts to confirm or disprove this suspicion by an X-ray structure analysis or by mass spectrometry, were unsuccessful as yet.

Unlike in pyrazine complexes carrying trans $-\mathrm{PtCl}_{2} \mathrm{~L}$ entities with $\mathrm{L}=$ phosphine or ethylene, ${ }^{32}$ in the compounds described herein no dynamic processes were observed in solution. Preliminary NMR studies indicate that the pz box $\mathbf{5}$ is remarkably inert toward nucleobases when kept in aqueous solution.

Compound 5 and Anions. Considering the solid state structure of 5 (Figure 7) and following up on an earlier finding that cationic Pt containing cycles with heterocyclic ligands can act as anion receptors, ${ }^{28 a, 33}{ }^{1} \mathrm{H}$ NMR spectra of 5 in $\mathrm{D}_{2} \mathrm{O}$ in the presence of increasing amounts of alkali salts $\left(\mathrm{H}_{2} \mathrm{PO}_{4}{ }^{-}, \mathrm{SO}_{4}{ }^{2-}, \mathrm{F}^{-}\right)$were performed. However, they did not provide any indication of anion binding in water considering the insensitivity of the pz resonance of 5 .

Related Pyrazine Compounds. In addition to the pz complexes described above, we have observed formation of related compounds in solution in a number of cases. The identification of compounds was straightforward on the basis of ${ }^{1} \mathrm{H}$ NMR spectroscopy. For example, $\left[\mathrm{enPt}(\mathrm{pz})_{2}\right]^{2+}$ is identified by its pz multiplets centered at $8.94 \mathrm{ppm}\left({ }^{3} J\left({ }^{195} \mathrm{Pt}{ }^{1} \mathrm{H}\right), 37\right.$ $\mathrm{Hz})$ and $8.00 \mathrm{ppm}\left({ }^{3} \mathrm{~J}\left({ }^{195} \mathrm{Pt}^{-1} \mathrm{H}\right), 9 \mathrm{~Hz}\right)$ and its $\mathrm{CH}_{2}$ resonance at $2.85 \mathrm{ppm}\left({ }^{3} J\left({ }^{195} \mathrm{Pt}-{ }^{1} \mathrm{H}\right), 44\right.$ $\mathrm{Hz}$ ). $\left[\mathrm{enPd}(\mathrm{pz})_{2}\right]^{2+}$ has its pz multiplets at 8.94 and $8.84 \mathrm{ppm}$ and the $\mathrm{CH}_{2}$ resonance of the en ligand at $2.94 \mathrm{ppm}$.

\section{Summary}

The compounds prepared in this work confirm the good ligating properties of pyrazine for $\mathrm{Pt}^{\mathrm{II}}$, which is somewhat unexpected considering the low basicity of the pz ligand itself. Both complexes with monodentate and bidentate bridging metal binding patterns have been 
isolated. Formation of the cyclic tetramer $\mathbf{5}$ conforms to expectations of the "molecular library approach" which predicts a molecular box when two ditopic building blocks with $90^{\circ}$ and $180^{\circ}$ angles, respectively, are combined.

Acknowledgements. This work was supported by the Deutsche Forschungsgemeinschaft, the Fonds der Chemischen Industrie, COST D20 for a Short Term Scientific Mission to C. M., and an Enterprise Ireland International Collaboration Grant. We thank Mr. Miguel Andres, Erasmus exchange student from Zaragoza, Spain, for his help on preparative work, Profs. Burkhard Costisella, Hans-Lothar Keller and Dr. Thorsten Oldag for helpful discussions.

Supporting Information Available: X-ray crystallographic files in CIF format. This material is available free of charge via the Internet at http://pubs.acs.org for compounds $\mathbf{3}, \mathbf{4 b}$, 5 and 7. The CIF for compound $\mathbf{1}$ is available from the Cambridge Crystallographic Data Centre (CCDC No. 252454), http://www.ccdc.cam.ac.uk. 


\section{References}

(1) (a) Creutz, C. Prog. Inorg. Chem. 1983, 30, 1. (b) Taube, H. Angew. Chem. Int. Edit. 1984, 23, 329.

(2) See, e.g.: Cotton, F. A.; Kim, Y.; Ren, T. Inorg. Chem. 1992, 31, 2608.

(3) (a) Ito, T.; Hamaguchi, T.; Nagino, H.; Yamaguchi, T.; Washington, J.; Kubiak, C. P. Science 1997, 277, 660. (b) Ito, T.; Hamaguchi, T.; Nagino, H.; Yamaguchi, T.; Kido, H.; Zavarine, I. S.; Richmond, T.; Washington, J.; Kubiak, C. P. J. Am. Chem. Soc. 1999, 121, 4625 .

(4) (a) Londergan, C. H.; Salsman, J. C.; Ronco, S.; Dolkas, L. M.; Kubiak, C. P. J. Am. Chem. Soc. 2002, 124, 6236. (b) Londergan, C. H.; Kubiak, C. P. Chem. Eur. J. 2003, 9,5962 .

(5) See, e.g.: (a) Ford, P.; Rudd, D. P.; Gaunder, R.; Taube H. J. Am. Chem. Soc. 1968, 90, 1187. (b) Taube, H. Pure Appl. Chem. 1979, 51, 901. (c) Slep, L. D.; Pollak, S.; Olabe, J. A. Inorg. Chem. 1999, 38, 4369.

(6) (a) Chen, Y.; Shepherd, R. E. Inorg. Chem. 1998, 37, 1249. (b) Krumm, M.; Zangrando, E.; Randaccio, L.; Menzer, S.; Lippert, B. Inorg. Chem. 1993, 32, 700.

(7) See, e.g.: (a) Carlucci, L.; Ciani, G.; Proserpio, D. M.; Sironi, A. Angew. Chem. Int. Edit. 1995, 34, 1895. (b) Carlucci, L.; Ciani, G.; Proserpio, D. M.; Sironi, A. J. Am. Chem. Soc. 1995, 117, 4562. (c) Lu, J.; Paliwala, T.; Lim, S. C.; Yu, C. ; Niu, T. ; Jacobsen, A. B. Inorg. Chem. 1997, 36, 923. (d) Tong, M.-L.; Chen, X.-M.; Yu, X.L.; Mak, T. C. W. J. Chem. Soc., Dalton Trans. 1998, 5. (e) Kondo, M.; Okubo, T.; Asami, A.; Noro, S.-i.; Yoshitoni, T.; Kitagawa, S.; Ishii, T.; Matsuzaka, H.; Seki, K. Angew. Chem. Int. Edit. 1999, 38, 140. (f) Carlucci, L.; Ciani, G.; Porta, F.; Proserpio, D. M.; Santagostini, L. Angew. Chem. Int. Edit. 2002, 41, 1907. (g) Kumagai, H.; Kawata, S.; Kitagawa, S. Inorg. Chim. Acta 2002, 337, 387. (h) 
Manson, J. L.; Arif, A. M.; Miller, J. S. Chem. Commun. 1999, 1479. (i) Kraft, S.; Hanuschek, E.; Beckhaus, R.; Haase, D.; Saak, W. Chem. Eur. J. 2005, 11, 969.

(8) For coordination polymers involving substituted pyrazine ligand see, e.g.: Näther, C.; Wriedt, M.; Jess, I. Inorg. Chem. 2003, 42, 2391 and refs. cited.

(9) (a) Iengo, E.; Mestroni, G.; Geremia, S.; Calligaris, M.; Alessio, E. J. Chem. Soc., Dalton Trans. 1999, 3361. (b) Komeda, S.; Kalayda, G. V.; Lutz, M.; Spek, A. L.; Yamanaka, Y.; Sato, T.; Chikuma, M.; Reedijk, J. J. Med. Chem. 2003, 46, 1210.

(10) (a) Slone, R. V.; Hupp, J. T.; Stern, C. L.; Albrecht-Schmitt, T. E. Inorg. Chem. 1996, 35, 4096. (b) Rajendran, T.; Manimaran, B.; Lee, F.-Y.; Lee, G.-H.; Peng, S.M.; Wang, C. M.; Lu, K.-L. Inorg. Chem. 2000, 39, 2016.

(11) Lau, V. C.; Berben, L. A.; Long, J. R. J. Am. Chem. Soc. 2002, 124, 9042.

(12) (a) Schweiger, M.; Seidel, S. R.; Arif, A. M.; Stang, P. J. Angew. Chem. Int. Edit. 2001, 40, 3467. (b) Yu, X.-Y.; Maekawa, M.; Kondo, M.; Kitagawa, S.; Jin, G.-X. Chem. Lett. 2001, 168.

(13) Raudaschl, G.; Lippert, B.; Hoeschele, J. D.; Howard-Lock, H. E.; Lock, C. J. L.; Pilon, P. Inorg. Chim. Acta 1985, 106, 141.

(14) Dhara, S. C. Indian J. Chem. 1970, 8, 193.

(15) Kauffman, G. B.; Cowan, D. O. Inorg. Synth. 1963, 7, 239.

(16) Tribolet, R.; Sigel, H. Eur. J. Biochem. 1987, 163, 353.

(17) Martin, R. B. Science 1963, 139, 1198.

(18) KappaCCD package; Nonius: Delft, The Netherlands, 1997. 
(19) Otwinowsky, Z.; Minor, W. DENZO and SCALEPACK. Methods Enzymol. 1997, $276,307$.

(20) Sheldrick, G. M. SADABS, Bruker AXS Inc.; Madison, WI, 2000.

(21) Sheldrick G. M. SHELXTL-PLUS (VMS), Siemens Analytical X-ray Instruments, Inc.: Madison, WI, 1990; SHELXL-93, Program for crystal structure refinement; University of Göttingen: Göttingen, 1993, SHELXL-97, Program for the refinement of crystal structures; University of Göttingen: Göttingen, 1997.

(22) Maresca, L.; Natile, G.; Fanizzi, F. P. J. Am. Chem. Soc. 1989, 111, 1492.

(23) Desiraju, G. R.; Steiner, T. The Weak Hydrogen Bond, Oxford University Press: Oxford, 1999.

(24) Sigel, R. K. O.; Freisinger, E.; Metzger, S.; Lippert, B. J. Am. Chem. Soc. 1998, 120,12000 .

(25) (a) Stang, P. J.; Olenyuk, B. Acc. Chem. Res. 1997, 30, 502. (b) Olenyuk, B.; Fechtenkötter, A.; Stang, P. J. J. Chem. Soc., Dalton Trans. 1998, 1707.

(26) Stang, P. J.; Cao, D. H. J. Am. Chem. Soc. 1994, 116, 4981.

(27) (a) Rauter, H.; Hillgeris, E. C.; Erxleben, A.; Lippert, B. J. Am. Chem. Soc. 1994, 116, 616. (b) Rauter, H.; Hillgeris, E. C.; Lippert, B. J. Chem. Soc., Chem. Commun. $1992,1385$.

(28) (a) Schnebeck, R. D.; Freisinger, E.; Glahé, F.; Lippert, B J. Am. Chem. Soc. 2000, 122, 1381 and refs. cited. (b) Beck, B.; Schneider, A.; Freisinger, E.; Hothenrich, D.; Erxleben, A.; Albinati, A.; Zangrando, E.; Randaccio, L.; Lippert, B. Dalton Trans. 2003, 2533. 
(29) Bing, X.; Dong, C.; Wenxia, T.; Kaibiei, Y.; Zhongyuang, Z. Acta Cryst. 1991, C47, 1805 .

(30) Literature value 0.6; c.f. Toma, H. E.; Stadler, E. Inorg. Chem. 1985, 24, 3085.

(31) Priqueler, J. R. L.; Rochon, F. D. Inorg. Chim. Acta 2004, 357, 2167.

(32) Albinati, A.; Isaia, F.; Kaufmann, W.; Sorato, C.; Venanzi, L. M. Inorg. Chem. 1989, $28,1112$.

(33) (a) Schnebeck, R. D.; Freisinger, E.; Lippert, B. J. Chem. Soc., Chem. Commun. 1999, 675. (b) Schnebeck, R. D.; Freisinger, E.; Lippert, B. Angew. Chem. Int. Edit. 1999, 38, 168. (c) Schnebeck, R. D.; Freisinger, E.; Glahé, F.; Lippert, B. J. Am. Chem. Soc. 2000, 122, 1381. 
Table 1. Crystallographic Data for Compounds $1,3, \mathbf{4 b}, \mathbf{5}$, and 7

\begin{tabular}{|c|c|c|c|c|c|c|}
\hline & & 1 & 3 & $4 \mathrm{~b}$ & 5 & 7 \\
\hline \multirow{2}{*}{\multicolumn{2}{|c|}{$\begin{array}{l}\text { chemical formula } \\
\text { fw, } \mathrm{g} \mathrm{mol}^{-1}\end{array}$}} & $\mathrm{C}_{8} \mathrm{H}_{14} \mathrm{~N}_{8} \mathrm{O}_{6} \mathrm{Pt}$ & $\mathrm{C}_{8} \mathrm{H}_{14} \mathrm{~N}_{8} \mathrm{O}_{6} \mathrm{Pt}$ & $\mathrm{C}_{4} \mathrm{H}_{16} \mathrm{Cl}_{4} \mathrm{~N}_{6} \mathrm{O}_{8} \mathrm{Pt}_{2}$ & $\mathrm{C}_{16} \mathrm{H}_{47.33} \mathrm{~N}_{24} \mathrm{O}_{27.67} \mathrm{Pt}_{4}$ & $\mathrm{C}_{28} \mathrm{H}_{48} \mathrm{Cl}_{5} \mathrm{~N}_{12} \mathrm{O}_{22} \mathrm{AgPt}_{2}$ \\
\hline & & 513.36 & 513.36 & 808.21 & 1799.05 & 1580.08 \\
\hline \multicolumn{2}{|c|}{ space group } & $\mathrm{P} 2_{1} / \mathrm{n}$ (No. 14) & $\mathrm{P} 2_{1} / \mathrm{n}$ (No. 14$)$ & P-1 (No. 2) & C2/c (No. 15) & C2/c (No. 15) \\
\hline \multicolumn{2}{|c|}{$a, \AA$} & $5.810(1)$ & $7.860(2)$ & $10.429(2)$ & $22.287(4)$ & $34.927(7)$ \\
\hline \multicolumn{2}{|c|}{$b, \AA$} & $15.870(3)$ & $11.126(2)$ & $10.488(2)$ & $18.922(4)$ & $10.663(2)$ \\
\hline \multicolumn{2}{|c|}{$c, \AA$} & $16.473(3)$ & $8.955(2)$ & $10.575(2)$ & $32.188(6)$ & $13.479(3)$ \\
\hline \multicolumn{2}{|c|}{$\alpha, \operatorname{deg}$} & 90 & 90 & $93.30(3)$ & 90 & 90 \\
\hline \multicolumn{2}{|c|}{$\beta, \operatorname{deg}$} & 95.61(3) & 103.41(3) & $118.70(3)$ & $98.76(3)$ & $98.82(3)$ \\
\hline \multirow{2}{*}{\multicolumn{2}{|c|}{$\gamma, \operatorname{deg}$}} & 90 & 90 & $116.29(3)$ & 90 & 90 \\
\hline & & $1511.6(5)$ & $761.7(3)$ & $854.2(3)$ & $13416(4)$ & $4960.6(17)$ \\
\hline \multirow[t]{2}{*}{1} & $\mathbf{V}, \AA^{3}$ & & & & & \\
\hline & & 4 & 2 & 2 & 12 & 4 \\
\hline \multirow[t]{2}{*}{2} & $\mathbf{Z}$ & & & & & \\
\hline & & $293(2)$ & $293(2)$ & $163(2)$ & $100(2)$ & $120(2)$ \\
\hline \multirow[t]{2}{*}{3} & $\mathbf{T}, \boldsymbol{K}$ & & & & & \\
\hline & & 0.71073 & 0.71073 & 0.71073 & 0.71073 & 0.71073 \\
\hline \multirow[t]{2}{*}{4} & $\lambda, \AA$ & & & & & \\
\hline & $\mathbf{D}_{\text {calcd, }} \mathrm{g} \mathrm{cm}^{-3}$ & 2.256 & 2.238 & 3.142 & 2.682 & 2.116 \\
\hline 5 & $\mu, m m^{-1}$ & 9.329 & 9.256 & 17.032 & 12.592 & 6.374 \\
\hline 7 & $\begin{array}{l}\text { final } \mathbf{R} \text { indices }[\mathbf{I}> \\
2 \sigma(\mathrm{I})]^{\mathrm{a}}\end{array}$ & $R 1=0.0396, w R 2=0.0940$ & $R 1=0.0178, w R 2=0.0372$ & $R 1=0.0208, w R 2=0.0510$ & $R 1=0.0395, w R 2=0.0467$ & $R 1=0.0304, w R 2=0.0531$ \\
\hline 8 & $\mathbf{R}$ indices $(\text { all data })^{\mathbf{a}}$ & $R 1=0.0620, w R 2=0.0975$ & $R 1=0.0395, w R 2=0.0397$ & $R 1=0.0238, w R 2=0.0522$ & $R 1=0.1623, w R 2=0.0593$ & $R 1=0.0534, w R 2=0.0593$ \\
\hline
\end{tabular}

${ }^{a} R 1=\Sigma|| F_{\mathrm{o}}|-| F_{\mathrm{c}}\|/ \Sigma\| F_{\mathrm{o}} \mid, w R 2=\left[\Sigma w\left(F_{\mathrm{o}}{ }^{2}-F_{\mathrm{c}}{ }^{2}\right)^{2} / \Sigma w\left(F_{\mathrm{o}}{ }^{2}\right]^{1 / 2}\right.$. 
Table 2. ${ }^{1} \mathrm{H}$ NMR Data of Pyrazine Complexes in $\mathrm{D}_{2} \mathrm{O}, \mathrm{pD} 3$ - 5

\begin{tabular}{|c|c|c|c|c|c|}
\hline Comp & 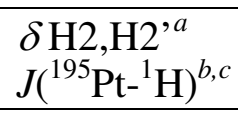 & & 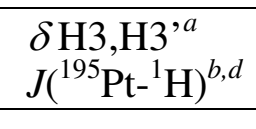 & $\begin{array}{l}\delta \mathrm{CH}_{2} \\
\left.J\left({ }^{195} \mathrm{Pt}^{1}{ }^{1} \mathrm{H}\right)\right)^{b, c}\end{array}$ & $\begin{array}{l}\delta \mathrm{CH}_{3} \\
J\left({ }^{195} \mathrm{Pt}-{ }^{1} \mathrm{H}\right){ }^{b, c}\end{array}$ \\
\hline 1 & $\begin{array}{c}8.968 \\
39\end{array}$ & & $\begin{array}{c}8.778 \\
12\end{array}$ & & \\
\hline 2 & $\begin{array}{c}9.154 \\
39\end{array}$ & & $\begin{array}{c}8.835 \\
11\end{array}$ & $\begin{array}{c}3.151 \\
26.4\end{array}$ & $\begin{array}{c}2.818 \\
33.6\end{array}$ \\
\hline 3 & $\begin{array}{c}9.004 \\
42\end{array}$ & & $\begin{array}{c}8.873 \\
11\end{array}$ & & \\
\hline $4 b$ & & $\begin{array}{l}9.036 \\
36^{b, c}\end{array}$ & & & \\
\hline 5 & & $\begin{array}{c}9.170 \\
32^{b, c} ; 5^{b, d}\end{array}$ & & & \\
\hline 6 & & $9.497^{e}$ & & $3.107^{e}$ & $2.697^{e}$ \\
\hline
\end{tabular}

in ppm; center of multiplet in $\mathrm{Hz}$

${ }^{3} J$ coupling

${ }^{4} J$ coupling

${ }^{195} \mathrm{Pt}$ satellites not observed 


\section{Figure Legends}

Figure 1. View of $c i s-\left[\left(\mathrm{NH}_{3}\right)_{2} \mathrm{Pt}(\mathrm{pz})_{2}\right]\left(\mathrm{NO}_{3}\right)_{2}(\mathbf{1})$. Selected structural details (distances in $[\AA]$, angles in $\left.\left[{ }^{\circ}\right]\right)$ : Pt-N1, 2.048(6); Pt-N2, 2.065(6); Pt-N1a, 2.022(5); Pt-N1b, 2.040(4); N1Pt-N2, 88.5(3); N1a-Pt-N1b, 89.6(2).

Figure 2. View of trans- $\left[\left(\mathrm{NH}_{3}\right)_{2} \mathrm{Pt}(\mathrm{pz})_{2}\right]\left(\mathrm{NO}_{3}\right)_{2}(3)$ Selected structural details (distances in $[\AA]$, angles in $\left.\left[^{\circ}\right]\right)$ : Pt-N11, 2.011(3); Pt-N1, 2.041(3); N11-Pt-N1, 88.98(12).

Figure 3. Hydrogen bonding between pz ligands of 1. Intermolecular distances between $\mathrm{N}$ and $\mathrm{C}$ sites are 3.283(9) $\AA$ (rings a and $\mathrm{a}^{*}$ ) and 3.264(8) $\AA$ (rings $\mathrm{b}$ and $\mathrm{b}^{*}$ ).

Figure 4. View of $c i s-\left[\left\{\left(\mathrm{NH}_{3}\right)_{2} \mathrm{PtCl}\right\}_{2}(\mathrm{pz})\right]\left(\mathrm{ClO}_{4}\right)_{2}(\mathbf{4 b})$. Selected structural details (distances in $[\AA ̊ \AA]$, angles in $\left[^{\circ}\right]$, see also text): Pt1-Cl11, 2.292(2); Pt2-Cl21, 2.299(2); N11Pt1-N12, 88.9(2); N4-Pt1-Cl11, 90.8(1); N21-Pt2-N22, 89.5(2); N1-Pt2-Cl21, 90.5(1).

Figure 5. Side and top view of pairs of cations of $\mathbf{4 b}$.

Figure 6. View of cation of open pyrazine box cis- $\left[\left\{\left(\mathrm{NH}_{3}\right)_{2} \mathrm{Pt}(\mathrm{pz})\right\}_{4}\right]^{8+}(\mathbf{5})$. Only one of two crystallographically independent cations (I) is depicted.

Figure 7. Detail of interaction of cation (I) of $\mathbf{5}$ with nitrate anion $\mathrm{N}(30)$, which is partially inserted in the open pyrazine box. Oxygen atom $\mathrm{O} 33$ is pointing toward the center of the box, while $\mathrm{O} 31$ makes a contact with a Pt from a neighboring cation.

Figure 8. View centrosymmetric cation $\left[\left\{(\text { tmeda }) \operatorname{Pt}(\mathrm{pz})_{2}\right\}_{2} \mathrm{Ag}\right]^{5+}(7)$.

Figure 9. Interactions of Z-shaped cations of $\mathbf{7}$ to produce an extended structure of open pyrazine boxes. The views are perpendicular to the array of the boxes. 
Figure 10: Partial insertion of perchlorate anion $\mathrm{Cl}(1) \mathrm{O}_{4}{ }^{-}$in $\mathrm{Pt}_{2} \mathrm{Ag}_{2 / 2}$ box. The oxygen atom sticking furthest out of the box (O31) forms a long contact to an $\mathrm{Ag}^{+}$ion in the tape above.

Figure 11. Aromatic regions of ${ }^{1} \mathrm{H}$ NMR spectra $\left(\mathrm{D}_{2} \mathrm{O}\right)$ of $\mathbf{1}(\mathrm{pD} 5.9), \mathbf{3}(\mathrm{pD} 3), \mathbf{4 b}(\mathrm{pD} 5)$, and $\mathbf{5}$ (pD 4.3). ${ }^{195} \mathrm{Pt}$ satellites are pointed out. 


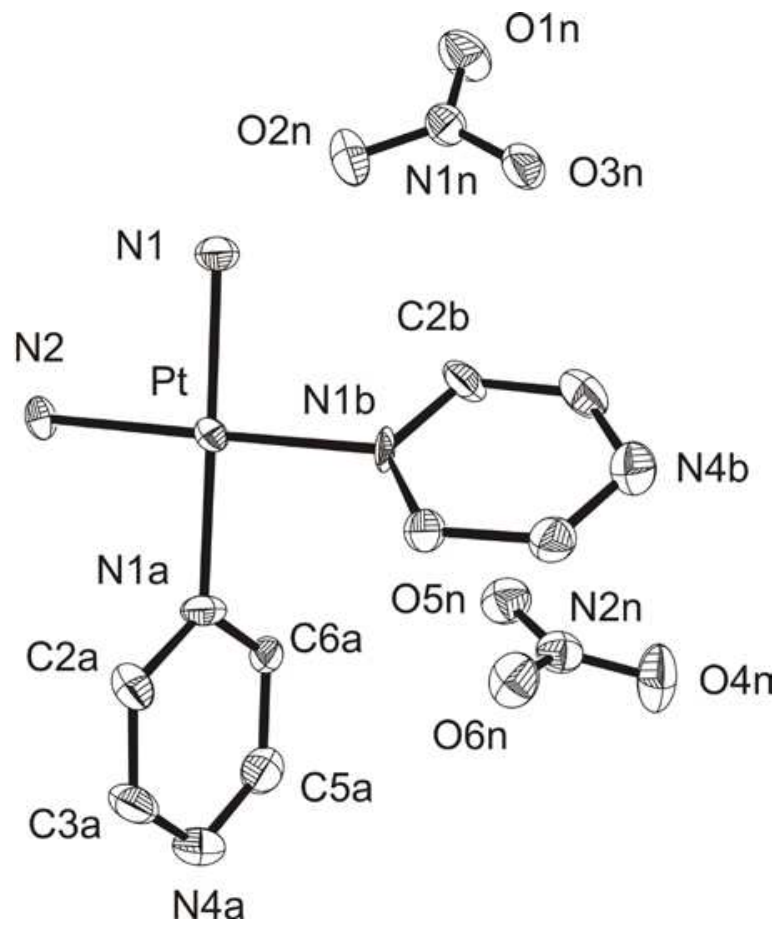

Figure 1 


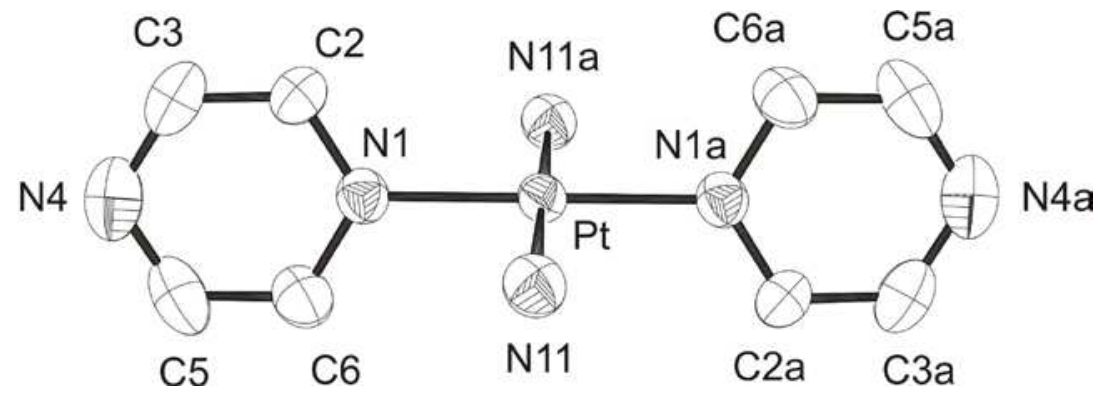

Figure 2 


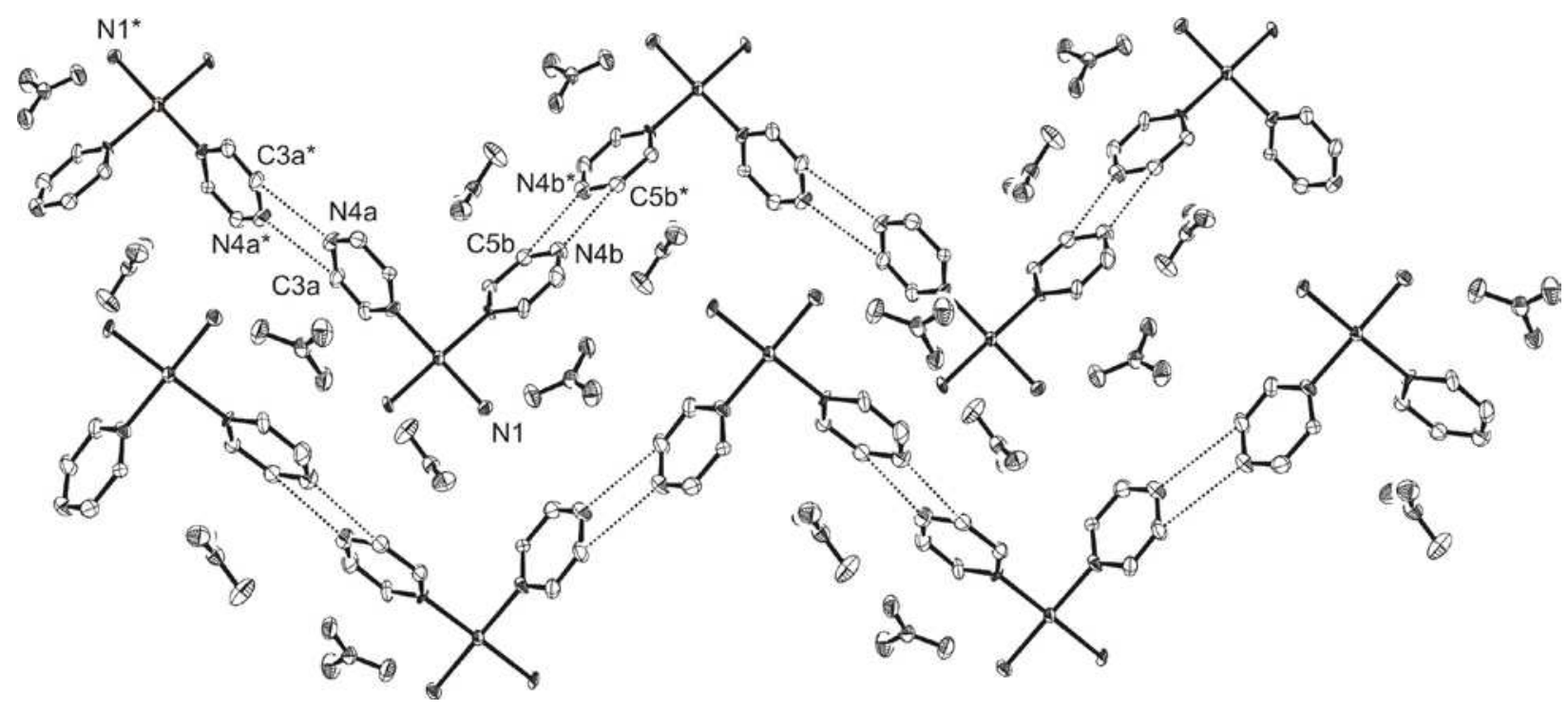

Figure 3 


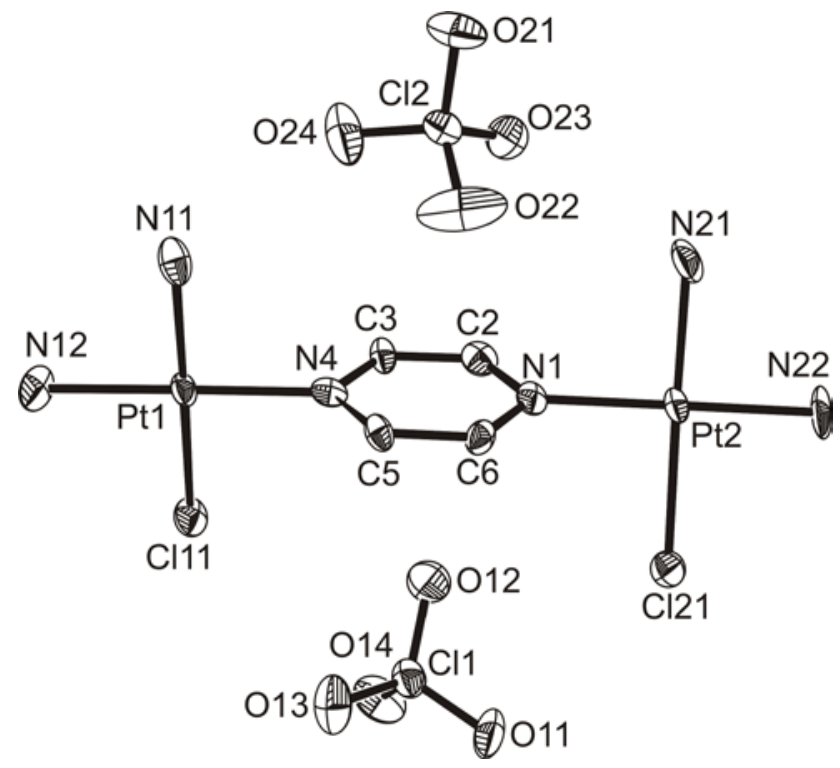

Figure 4 

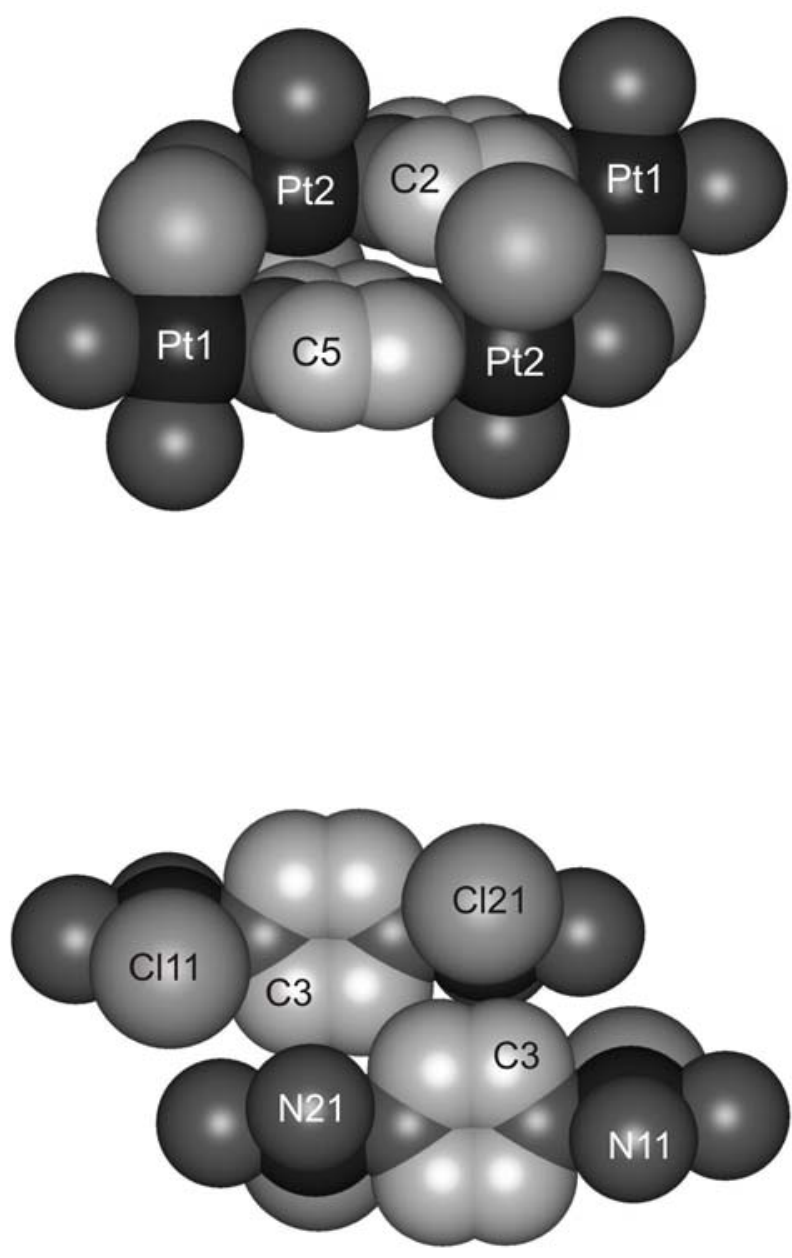

Figure 5 


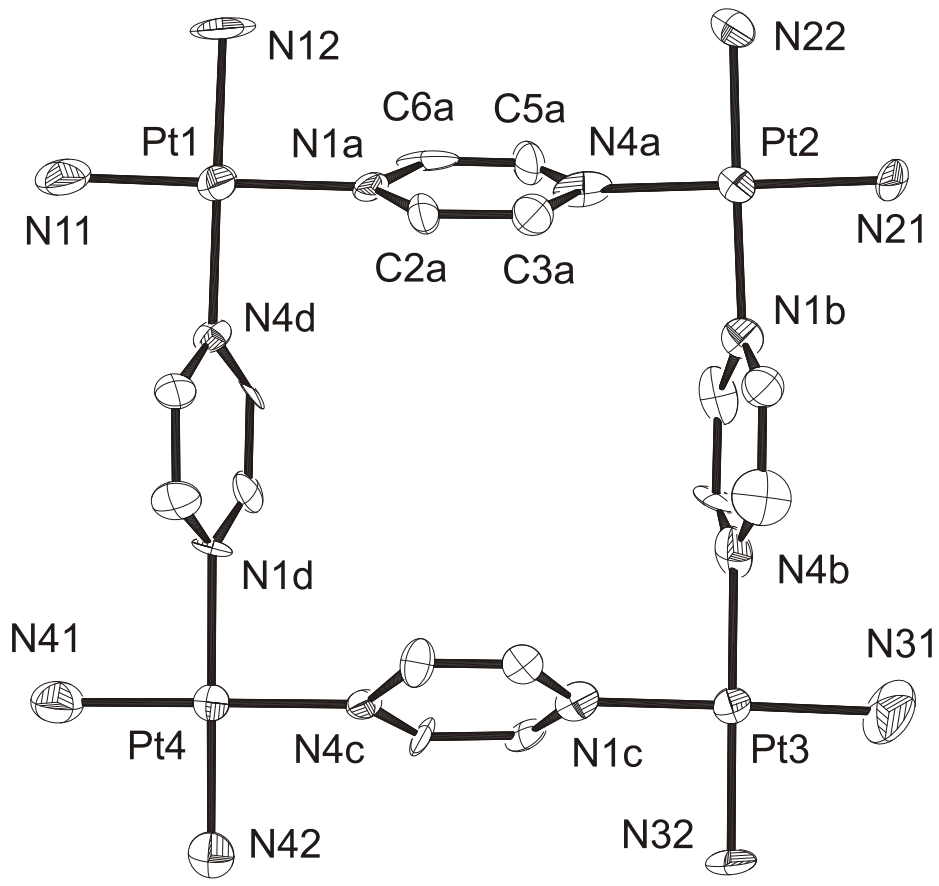

Figure 6 


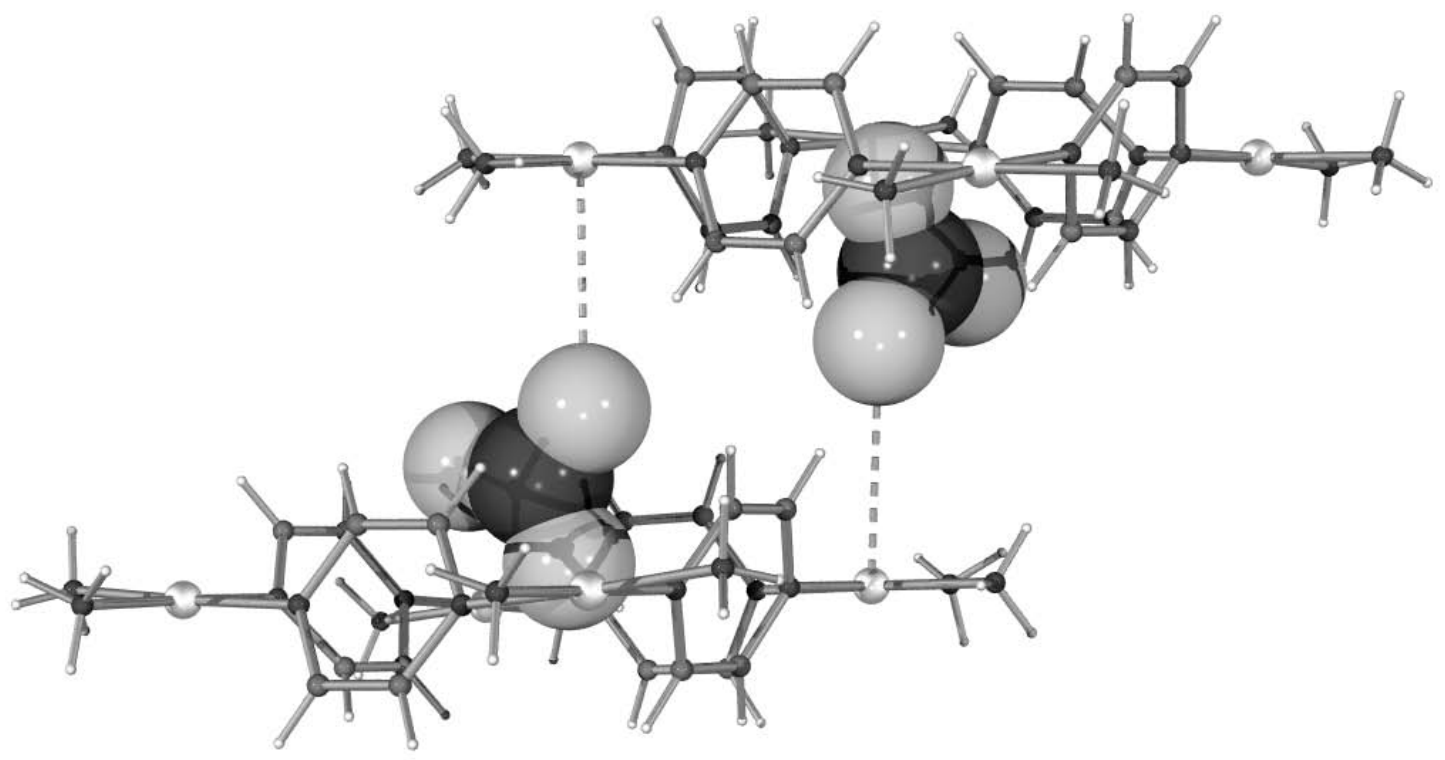

Figure 7 


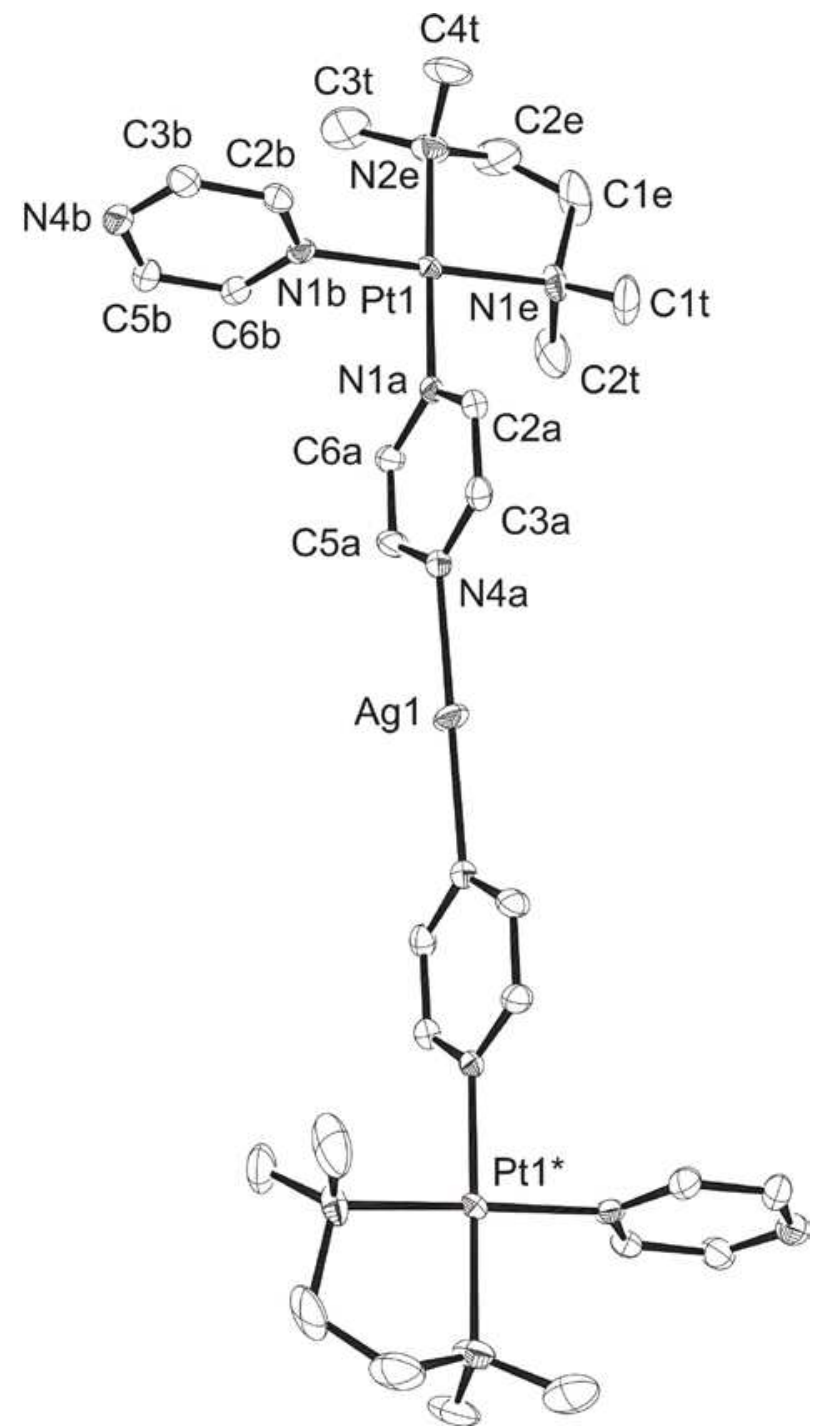

Figure 8 

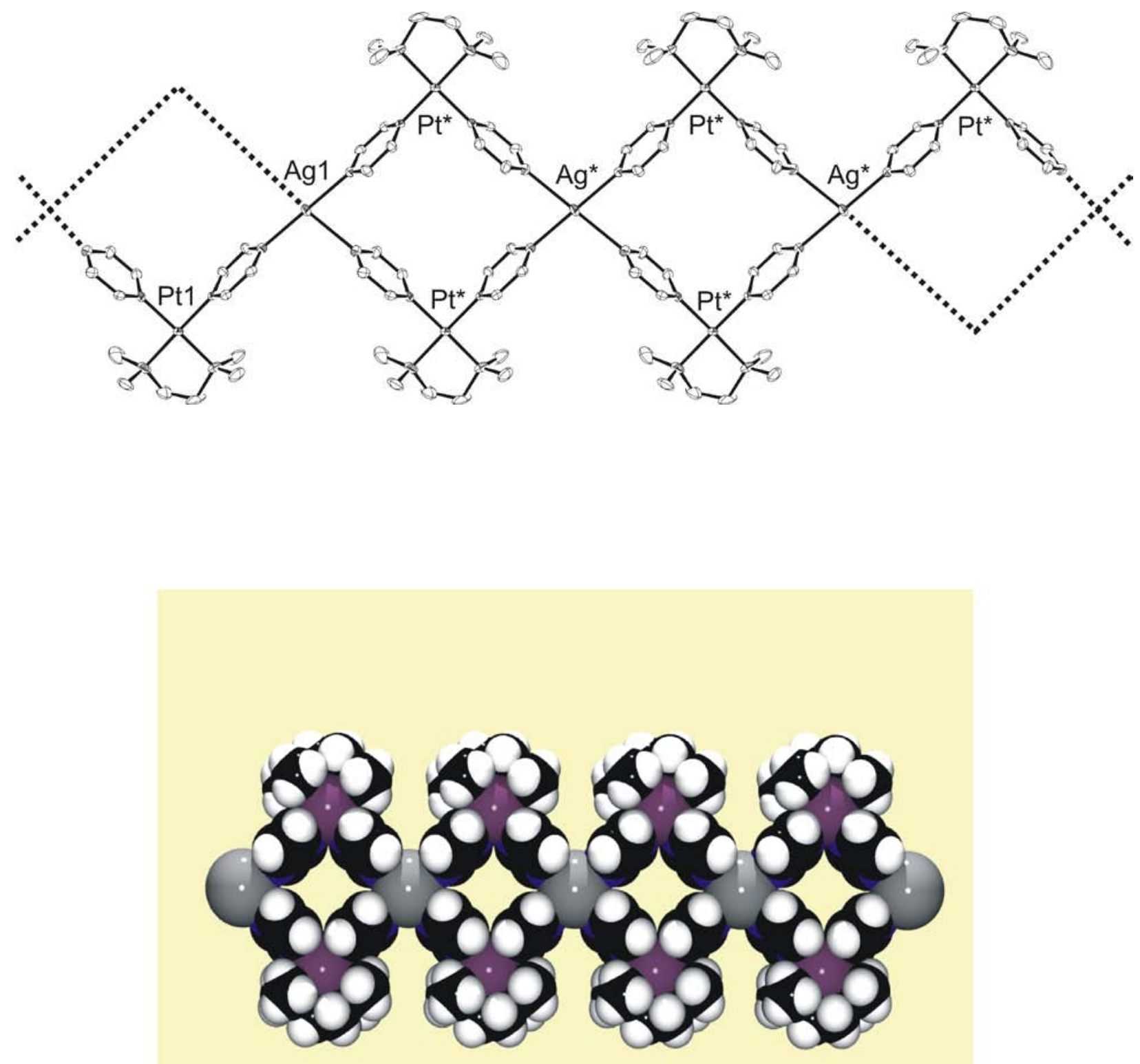

Figure 9 


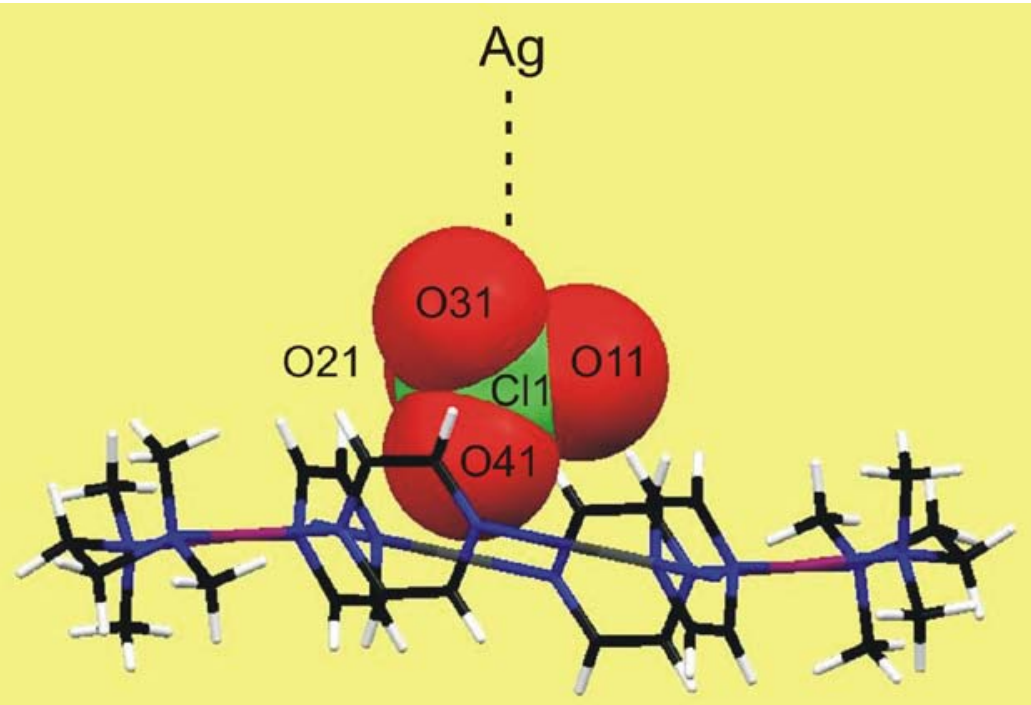

Figure 10 

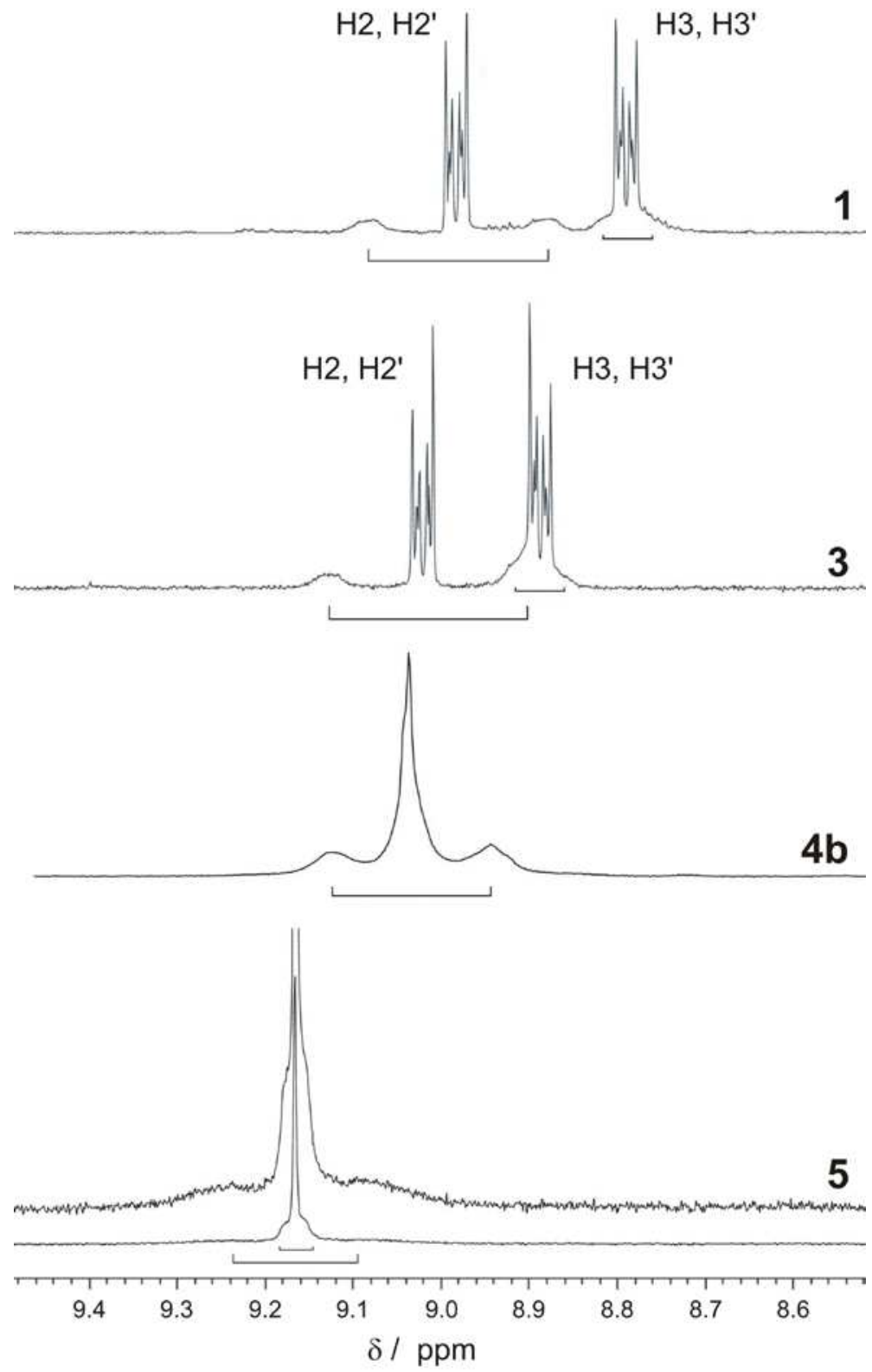

Figure 11 


\section{Table of Contents}

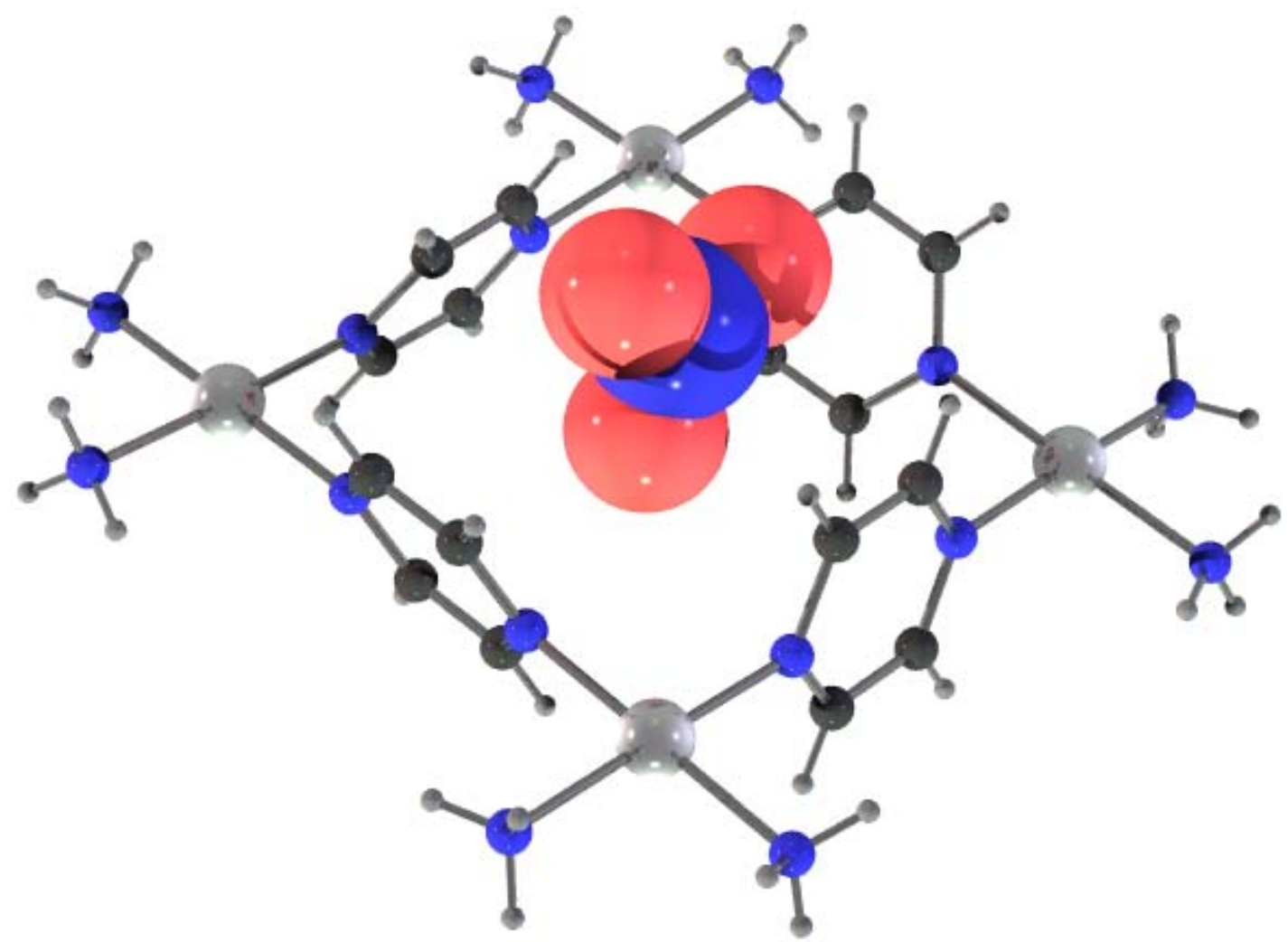

Pyrazine as a Building Block for Molecular Architectures with Pt ${ }^{\mathrm{II}}$

Michael Willermann, Clodagh Mulcahy, Roland K. O. Sigel, Marta Morell Cerdà, Eva Freisinger, Pablo J. Sanz Miguel, Michael Roitzsch, and Bernhard Lippert*

The cationic, open molecular box derived from Cisplatin and pyrazine, cis$\left[\left\{\left(\mathrm{NH}_{3}\right) \mathrm{Pt}(\mathrm{pz})\right\}_{4}\right]\left(\mathrm{NO}_{3}\right)_{8} \cdot 3 \mathrm{H}_{2} \mathrm{O}$ partially inserts a nitrate anion. 